Egyptian Journal of Aquatic Biology \& Fisheries

Zoology Department, Faculty of Science,

Ain Shams University, Cairo, Egypt.

ISSN $1110-6131$

Vol. 25(1): 141 - 160 (2021)

www.ejabf.journals.ekb.eg

\title{
Histological studies on the testicular cycle of grass carp, Ctenopharyngodon idella in related to gonadotrophic cells activity of the pituitary gland.
}

\author{
Mohamed A. Sheha ${ }^{1}$, Samah T Darwish ${ }^{2}$, Abd-Elhakim E. El-Gamal ${ }^{3}$, \\ Rania O. Barakat ${ }^{4}$ \\ 1 Head sector in MOPCO Company, Egypt. \\ 2. Zoology Department, Faculty of Science, El-Arish University, Egypt. \\ 3,4. National Institute of Oceanography and Fisheries (NIOF), Egypt \\ * Corresponding author: m.sheha987@gmail.com
}

ARTICLE INFO

Article History:

Received: Oct. 30, 2020

Accepted: Dec. 26, 2020

Online: Jan. 29, 2021

Keywords:

Gonadosomatic index, gonadotrophic cells, testes,

pituitary gland,

grass carp,

Ctenopharyngodon

idella.

\begin{abstract}
Ctenopharyngodon idella, the grass carp, has a reduced spawning season that extends from April to May. The biological parameters including, length at first male sexual maturity, are represented at length of $53 \mathrm{~cm}$ in which $50 \%$ of male grass carp matures. Furthermore, the gonadosomatic index (GSI) increased dramatically from January $0.264 \pm 0.08$ to a peak in April

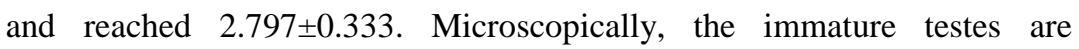
composed of developing spermatogenic cells, while the ripe tests contain mainly of sperms. The interstitial cells are situated between the seminiferous lobules. The adenohypophysis of the studied fish is divided into three regions; the rostral pars distalis, proximal pars distalis and pars intermedia. The gonadotrophic cells exhibited different degrees of secretory activity and hypertrophy during the sexual cycle. The authors finally concluded that there is a cyclic change in the testicular germ cells parallel with the gonadotrophic cell activity in the pituitary gland.
\end{abstract}

\section{INTRODUCTION}

The grass carp belongs to the family Cyprinidae and genus Ctenopharyngodon (Chilton and Muoneke, 1992). The native habitat extended from rivers to lakes in eastern Asia ( Lee et al., 1980). It was cultivated and widespread allover 80 countries worldwide (Fish Base, 2004). The grass carp are a good source of protein and exhibited biological activity of control the growth of aquatic weeds (Opuszynski \& Shireman, 1995; Mitchell \& Kelly, 2006). Due to the spread of aquatic plants in irrigating canals leading to water depletion, Ctenopharyngodon idella was introduced in Egypt as a biological control agent. Furthermore, the use of herbicides in the control of aquatic plants in the River Nile and irrigation canals in Egypt has been public health concern since 1990. The main issue of Egyptian grass carp production was its inability to spawn in ponds and lakes due to environmental differences from 
its natural habitat. Gonads prematurity was observed at temperatures above $80 \mathrm{~F}$. The failure of natural spawning of grass carp was attributed to the absence of nutritional, photoperiod and water temperature (Goodchild, 1999). Further effort was done to establish artificial spawning for hatchery production of offspring.

One of the most accurate approaches for determining the growth cycle of gonads is known to be the seasonal development of fish gonads (Sivakumaran et al., 2003). Histological research gives an actual state of gonads development and also important in determining the maturation period (Tingaud-Sequeira et al., 2008). The determination of the maturity stage is considered to be the final step that used for artificial spawning in hatcheries. According to the histological examination, Abu ElNasr (2016) divided the maturation of the Gerres oyena testes into eight stages; immature stage, development, virgin, maturing, mature, ripe and spawning.

The frequency percentages of the different germ cells occurring in the testicular lobules were taken as the key factor in classifying the phases of fish testes as defined by Chakrabarti and Choudhury (2015). The testes of Salmo trutta possessed spermatogonia A during the resting period and then further differentiation during maturity stage leading to increase of spermatocytes, spermatids, and finally spermatozoa (Dziewulska and Domagała, 2003). Abu El-Nasr (2016) and Duarte et al. (2017) reported that the spermatogenetic cells of Gerres oyena and Loricariichthys spixii are differentiated into six stages namely: spermatogonia A \& B, primary \& secondary spermatocytes spermatid, and spermatozoa.

The cells of adenohypophysis varied between fishes. Bagrus bajad had only one basophilic cell, known as gonadotrophs which showed a degree of granulation and hypertrophy during the sexual maturation (El-gamal and El Greisy,2008). Mousa (1994), however indicated that there are two types of gonadotrophs in Mugil cephalus pituitary gland that showed a degree of development during the sexual maturation of the testes.

\section{Aim of the work:}

Few studies have been performed on the testes of grass carp, so the current research was designed to investigate the cyclical changes in grass carp testes associated with gonadotrophic cell activity in the pituitary gland in order to provide more knowledge required in future studies for induction of spawning.

\section{MATERIALS AND METHODS}

\section{Determination of water temperature:}

The temperature of the water was measured five 5 days a week. During the period extended from January to December 2018, the averages of minimum and maximum temperatures were recorded at the end of each month.

\section{Fish collection:}

During the mentioned experimental period, approximately 40 alive male grass carp fish specimens were captured using special nets from the Damietta branch of the 
River Nile near to Faraskour city. Their total lengths $(30-67 \mathrm{~cm})$ and body weights $(2$ to $5 \mathrm{~kg}$ ) were recorded. The color and shape of testes were recorded after the male fishes were sacrificed to identify the morphological stages of testes.

The gonadosomatic index (GSI) was determined according to several authors (Yoneda et al., 2001; El-Gamal, 2001; El Garabawy et al., 2003 and Ahmet et al., 2004) by using the following equation:

Gonad weight $(\mathrm{g})$

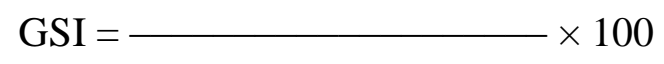

Gutted weight $(\mathrm{g})$

\section{Histological techniques:}

Small pieces of testis were dissected and fixed 10\% phosphate buffered formalin. The pituitary gland was carefully removed and then mounted in bouin fixative. Both specimens were dehydrated in ascending concentrations of ethyl alcohol, cleared in xylene and mounted in molten paraplast $58-62^{\circ} \mathrm{C}$. Serial histological sections 4- $6 \mu \mathrm{m}$ thick were cut and stained with Harris's haematoxylin $\&$ eosin (Harris, 1900). For the pituitary gland, periodic acid Schiff's reagent (PAS) (McMannus, 1948) and alcian blue (AB) combined with PAS and orange G (OG) as well as PAS with orange $\mathrm{G}$ were carried out.

The phases of spermatogenesis have been histologically recognized with certain modifications, according to Tan (1985) and (Khallaf and Authman, 1991). The pattern of spermatogenic cells were visualized and outlined the monthly shifts of the testes over the annual reproductive cycle.

\section{Quantitative measurements:}

According to Assem (2004) and El-Gamal and El-Greisy (2008), the changes in gonadotrophic cells were reported by measuring the nuclear diameter of the pituitary cell types from five fishes in each stage.

\section{Scanning electron microscopy:}

Ripening testes samples were fixed in $2 \%$ phosphate buffered glutaraldehyde $(\mathrm{pH}$ 7.4). The samples were then dehydrated in ascending series of ethyl alcohol, followed by absolute acetone and allow to the critical-point dryer (HCP-2 critical point dryer, Hitachi, Tokyo, Japan). The samples were placed onto an aluminum stups, coating with gold by E101 ion sputters (Hitachi) and visualized and photographed by a Hitachi S-2400 scanning electron microscope.

\section{RESULTS}

During the collection of samples, the water temperature ranged from 12.16 to $14.66{ }^{\circ} \mathrm{C}$ in the winter season and gradually increased in the spring and summer seasons, reached tits highest temperature $\left(27.16{ }^{\circ} \mathrm{C}\right)$ in August. The water temperature decreased gradually and reached to $22^{\circ} \mathrm{C}$ at the end of November (Fig. $1)$. 


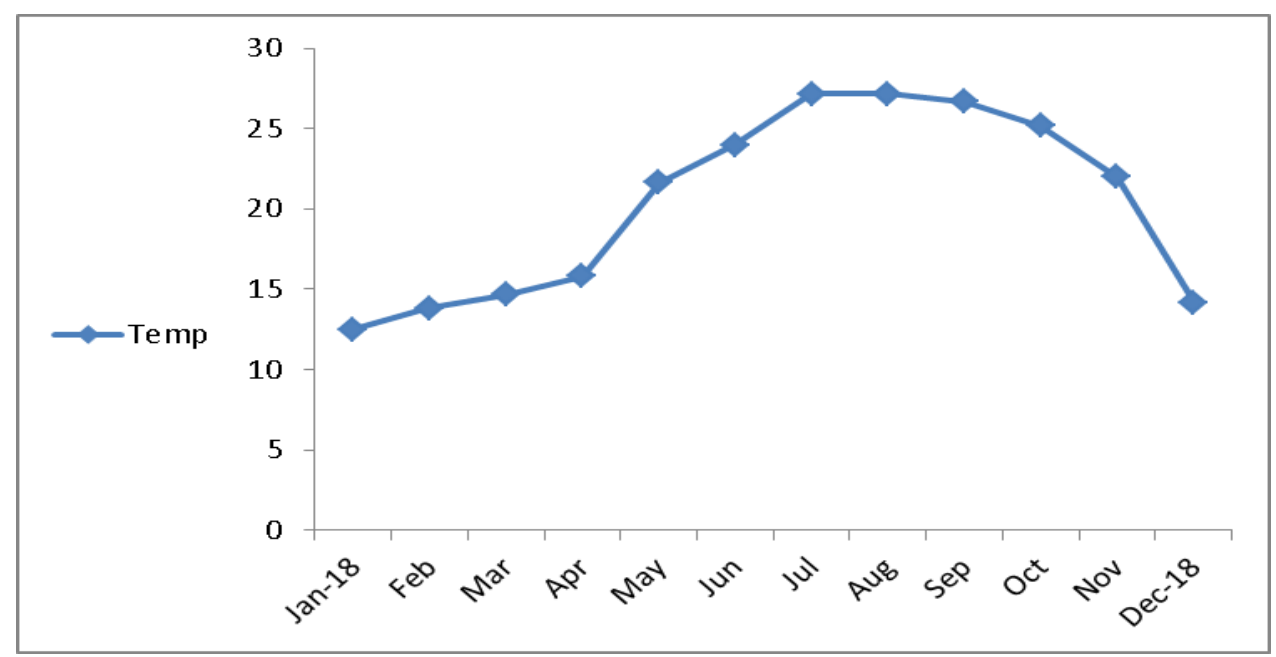

Fig. (1): Monthly fluctuation in temperature during sampling period

\section{Gonadosomatic index:}

(January-December 2018)

During the study period, the GSI increased sharply from $(0.264 \pm 0.08)$ in January and reached to increased peak in April (2.797 \pm 0.333$)$. The value of GSI level decreased sharply to $1.255 \pm 0.385$ in May. The GSI decreased steadily from $(0.242 \pm 0.014)$ in July and reached a minimum value of $0.115 \pm 0.004$ at the end of the reproductive season in December.as shown in Table (1) and Fig. (2).

\section{The length at the first sexual maturity of males:}

At the length of 29.9 to $45 \mathrm{~cm}$, all of the studied males were immature and their percentage reached to $100 \%$. The percentage of mature males was $20 \%$ at $50 \mathrm{~cm}$ and gradually increased to $100 \%$ at length of $65 \mathrm{~cm}$, as shown in Figure (3). The prediction the first sexual maturity of male grass carp was about $50 \%$ of males at 53 $\mathrm{cm}$ in length. 
Table (1): Monthly variations of the gonadosomatic index (GSI) of males grass carp, C. idella during the period from January to December, 2018

\begin{tabular}{||l||l||l||l||}
\hline \hline Months & Min. & Max. & $\begin{array}{c}\text { Average } \pm \\
\text { SD }\end{array}$ \\
\hline \hline Jan.2018 & 0.121 & 0.389 & $0.264 \pm 0.08$ \\
\hline \hline Feb & 0.13 & 0.188 & $0.162 \pm 0.019$ \\
\hline \hline Mar & 0.345 & 0.624 & $0.72 \pm 0.473$ \\
\hline \hline Apr & 2.1 & 3.1 & $2.797 \pm 0.333$ \\
\hline \hline May & 0.98 & 2.1 & $1.255 \pm 0.385$ \\
\hline \hline Jun & 0.59 & 0.67 & $0.621 \pm 0.026$ \\
\hline \hline Jul & 0.23 & 0.27 & $0.242 \pm 0.014$ \\
\hline \hline Aug & 0.16 & 0.221 & $0.196 \pm 0.019$ \\
\hline \hline Sep & 0.12 & 0.17 & $0.153 \pm 0.015$ \\
\hline \hline Oct & 0.11 & 0.15 & $0.138 \pm 0.034$ \\
\hline \hline Nov & 0.1 & 0.132 & $0.121 \pm 0.012$ \\
\hline \hline Dec.2018 & 0.11 & 0.12 & $0.115 \pm 0.004$ \\
\hline \hline
\end{tabular}

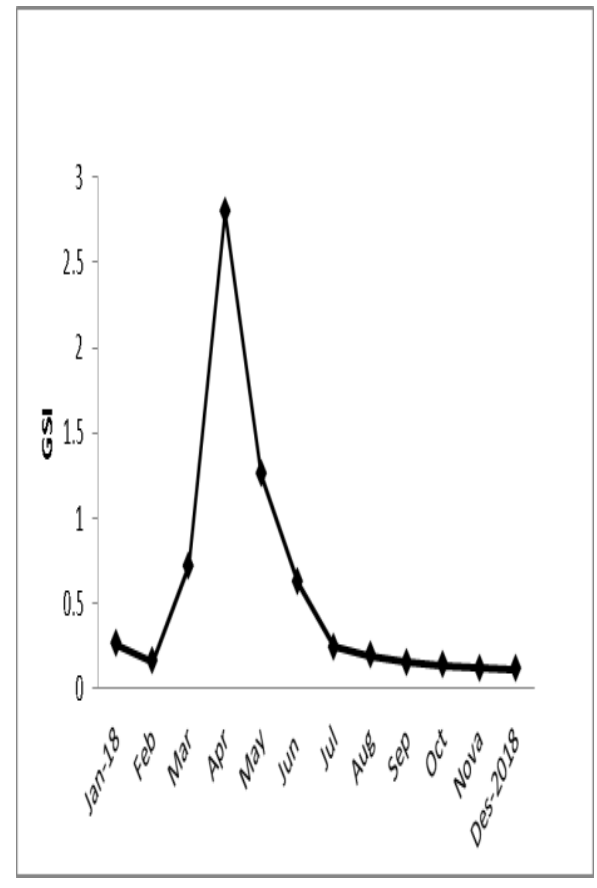

Fig. (2): Monthly variations of the gonadosomatic index (GSI) of males grass carp, $C$. idella during the period from January to December, 2018.

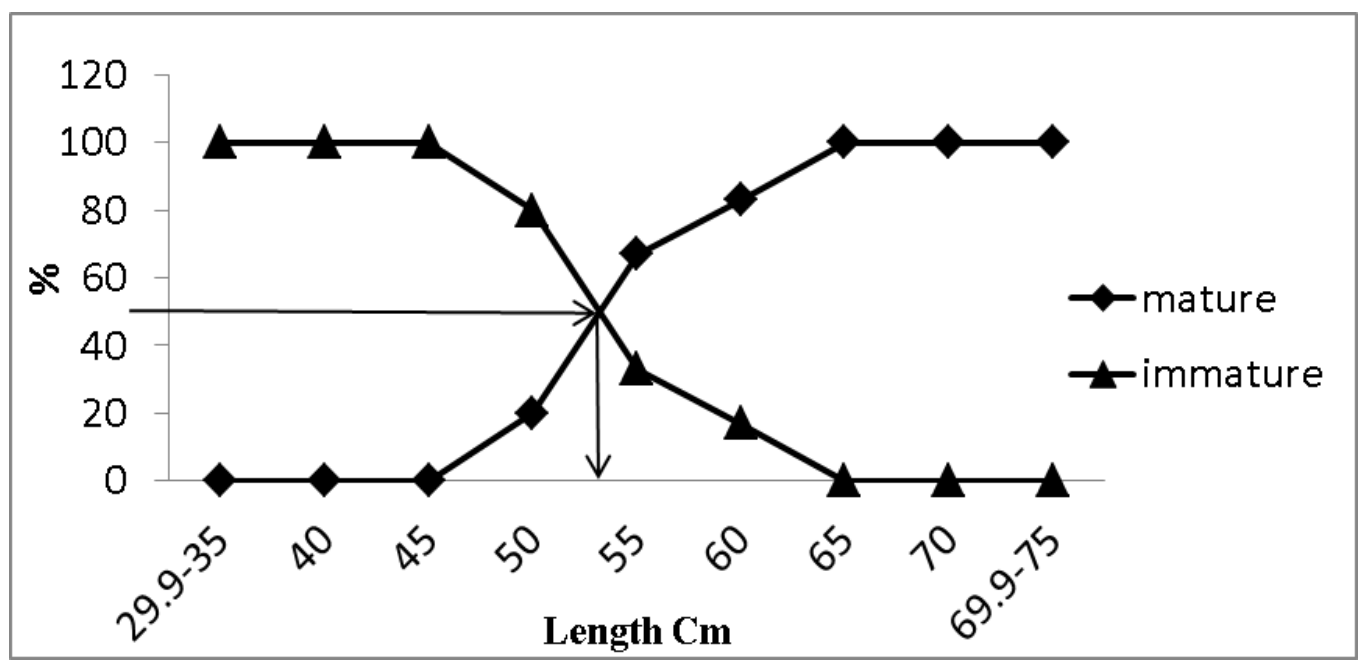

Fig. (3): The maturity stage at the first length of sexual maturity of males.

\section{Monthly variation of the testes during annual reproductive cycle:}

The annual reproductive cycle of the grass carp was divided into five stages, namely: immature, maturing, ripe, spawning and spent stages.

\section{1-Immature stage:}

All studied males were in the immature stage in January, and then in February, the percentage decreased to $80 \%$ and in March to $78 \%$. After June, the percentage of maturity increased from $10 \%$ in July to $100 \%$ in September. Only from October to 
January, the immature period steadily increased reached its highest peak at January. (Fig., 4).

\section{2-Maturing stage:}

In February, $20 \%$ of the maturing stage was observed and the percentage was increased to $22 \%$ during March. In May, this stage was not established until the end of the annual period (Fig., 4).

\section{3- Ripe stage}

The ripe stage was estimated in April with a percentage of about $100 \%$. This stage was recorded in May and then the percentage decreased to $77 \%$ in June. The mature stage was totally absent until the end of the spawning season, the ripe stage was totally absent (Fig., 4).

\section{4-Spawning stage:}

This stage was not detected during the period of spawning season.

\section{5-Spent stage:}

This stage was detected only in the three months; at the late of June $23 \%$, July 90\% and August 75\% (Fig., 4).

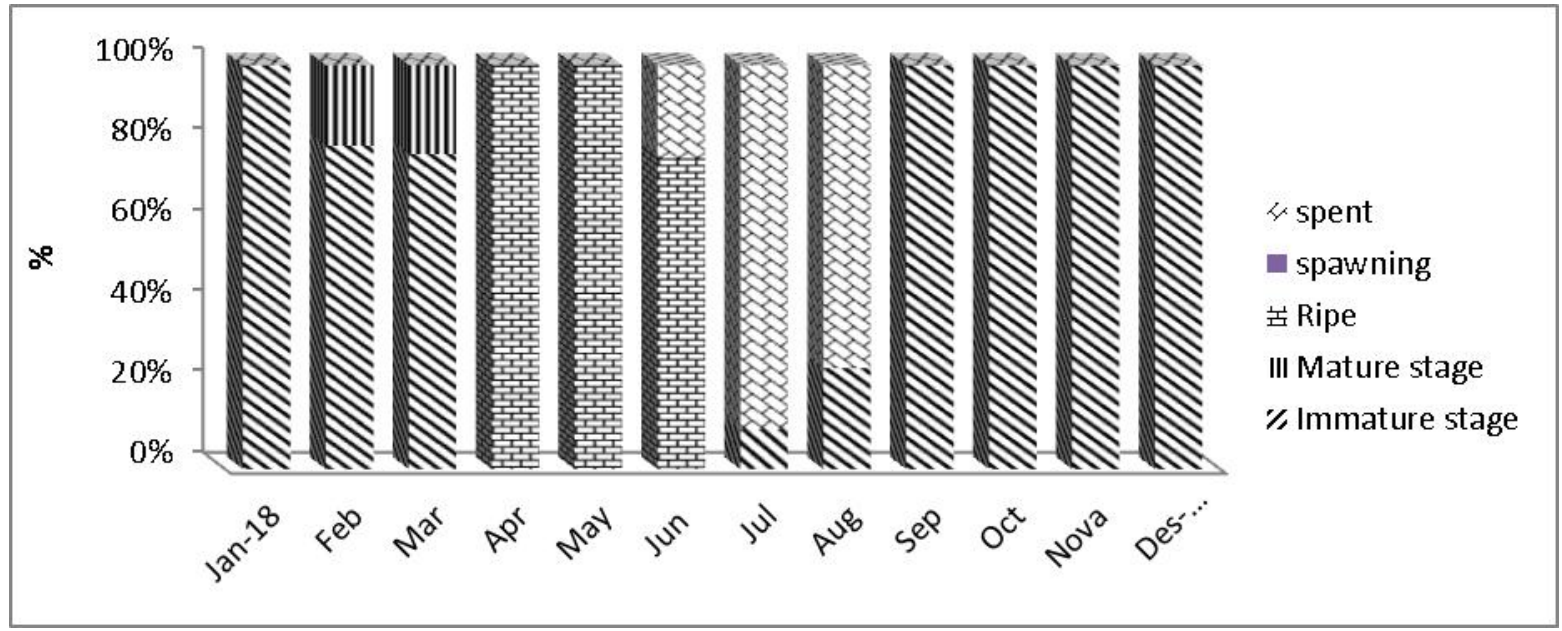

Fig. (4). Monthly distribution of the maturity stages in the testes of males grass carp, C. idella during the annual of reproductive cycle, 2018.

\section{Morphological observations on the testes:}

It is formed of an equal pair of elongated lobes, situated longitudinally in the dorsal part of the body cavity (Figs. 5A). During the immature stage, it is not visualized by naked eye. External sexual dimorphism can be detected at the onset of maturation when deciduous tubercles (pearl organs) are present on the dorsal and medial surfaces of the pectoral fins of male grass carp (Figs.5B\&C).

Based on their morphological criteria, the steps of testes maturation may be divided into five stages including; immature, maturing, ripe, spawning and spent. 


\section{1-Immature stage:}

The testes are delicate, thread-like-structure, translucent, and adherent to all side of the swim bladder. The overall length of the testis was approximately one-third of the body cavity (Fig. 5D).

\section{2-Maturing stage:}

In this stage, the testes were increased in size and became white in color. The testes were elongated and their length were extended up to two-thirds of the body cavity, with some red spots can be visible by naked eyes (Fig. 5E).

\section{3-Ripe stage:}

During this stage, the size of testes increased and became more elongated and creamy in color. The milt was extruded after fingers pressure on the abdomen of the fish (Fig. 5A).

\section{4-Spawning stage:}

This stage morphologically during the period of spawning season was not detected.

\section{5-Spent stage:}

In this stage, the testes were dorso-ventrally flattened and appeared as creamywhite, with scattered red spots which were visible with naked eyes. The length and width of testes were comparatively decreased and became flaccid in structure (Fig. $, 5 \mathrm{~F})$.

\section{Histological observations on the testes:}

Histologically, the testis of grass carp was formed of huge number of seminiferous lobules that surrounded with connective tissue capsule Fig. (6A). The interstitial cells were observed in the interlobular spaces especially in the mature stage Figure. (6B). The spermatogenesis was divided into five stages of spermatogenic cells, namely: spermatogonia, primary and secondary spermatocytes, spermatids and spermatozoa.

\section{1- Spermatogonia:}

The spermatogonia is the largest and the earliest cell type in the testicular lobules, measuring about $16 \mu \mathrm{m}$ as shown in Figs. 6(C). Spermatogonia A are situated, either singly or in group of two cells (Fig. 6C). They are varied from round to oval in shaped, with a large nucleus, measuring about $8 \mu \mathrm{m}$ in diameter and have thin layer of pale-staining cytoplasm (Fig. 6E).

The spermatogonia aligned close to the Sertoli cells and surrounded by the cytoplasmic processes that extended from it (Fig. 6F). The spermatogonia possessed centrally located nuclei with densely compacted heteroochromatin (Fig. 6A). The spermatogonia A were divided mitotically to produce similar daughter spermatogonia B but smaller in size ( $11 \mu \mathrm{m}$ in diameter) (Figs. 6E, G). 


\section{2-Primary spermatocytes:}

With advancement of development, spermatogonia B was further differentiated into primary and secondary spermatocytes via mitotic division. Primary spermatocytes reached to about $6 \mu \mathrm{m}$ in diameter (Fig. 6G).

\section{3-Secondary spermatocytes:}

The secondary spermatocytes were smaller in size, and have a diameter of about 5-6 $\mu \mathrm{m}$. They have been found in nests inside the lobules lumen. This stage was characterized with their indistinct cell outlines (Figs. 6G, H). The basophilic nucleus reached about $3 \mu \mathrm{m}$ in diameter. The secondary spermatocytes were divided meiotically to produce spermatids.

\section{4- Spermatids:}

The transition period between secondary spermatocytes and spermatids was short time, so it was rarely distinguished. Spermatids were somewhat smaller in size in comparison with the secondary spermatocytes and its diameter reached to 3-3.5 $\mu \mathrm{m}$ (Figs.6G\&H). The nucleus attained about $2.5 \mu \mathrm{m}$ and appeared homogeneous and deeply stained.

\section{5- Spermatozoa:}

The spermatids showed progressive metamorphosis into the mature sperms. Each sperm were distinguished by small rounded head and elongated tail. The sperm head had large condensed nucleus the sperms were crowded centrally in the lobules without any special arrangement (Fig.6H). The lumen of the seminiferous tubules was completely filled with sperms during the ripe stage. Investigation of the fine structure of the spermatozoa of grass carp by using scanning electron microscopy showed that the consisted of an ovoid head contained nucleus, cytoplasmic channel, short cone shaped mid piece and a long cylindrical flagellum (Figs. 7A,B).

\section{Morphological studies of the pituitary gland:}

The pituitary gland of grass carp acquired an oval shaped, was compressed dorso-ventrally and attached to the ventral region of the hypothalamus. It was connected by a thin cylindrical fundibular stalk called neurohypophysis that penetrated the gland mass through all parts particularly through its posterior part. The pituitary gland is surrounded with a thin sheath of dedicated connective tissue capsule. The gland was protected by the para-sphenoid bone located behind the optic chiasma in a bony chamber (Fig. 8A).

\section{Histological and histochemical observations on the cells of the pituitary gland in related to the maturation stages in the testes.}

Histologically, there were two major components; neurohypophysis $(\mathrm{NH})$ and adenohypophysis. The adenohypophysis was divided into three parts, namely: the rostral pars distalis (RPD), proximal pars distalis (PPD) and pars intermedia (PI) (Fig. $8 \mathrm{~B})$. The gonadotropic hormone secreting cells $(\mathrm{GTH})$ restricted mainly in proximal pars distalis (PPD). The most cells of pituitary glands in males are not change during the period of breading season, except the gonadotropic hormone secreting cells (GTH) (Figs. 8C,D). 

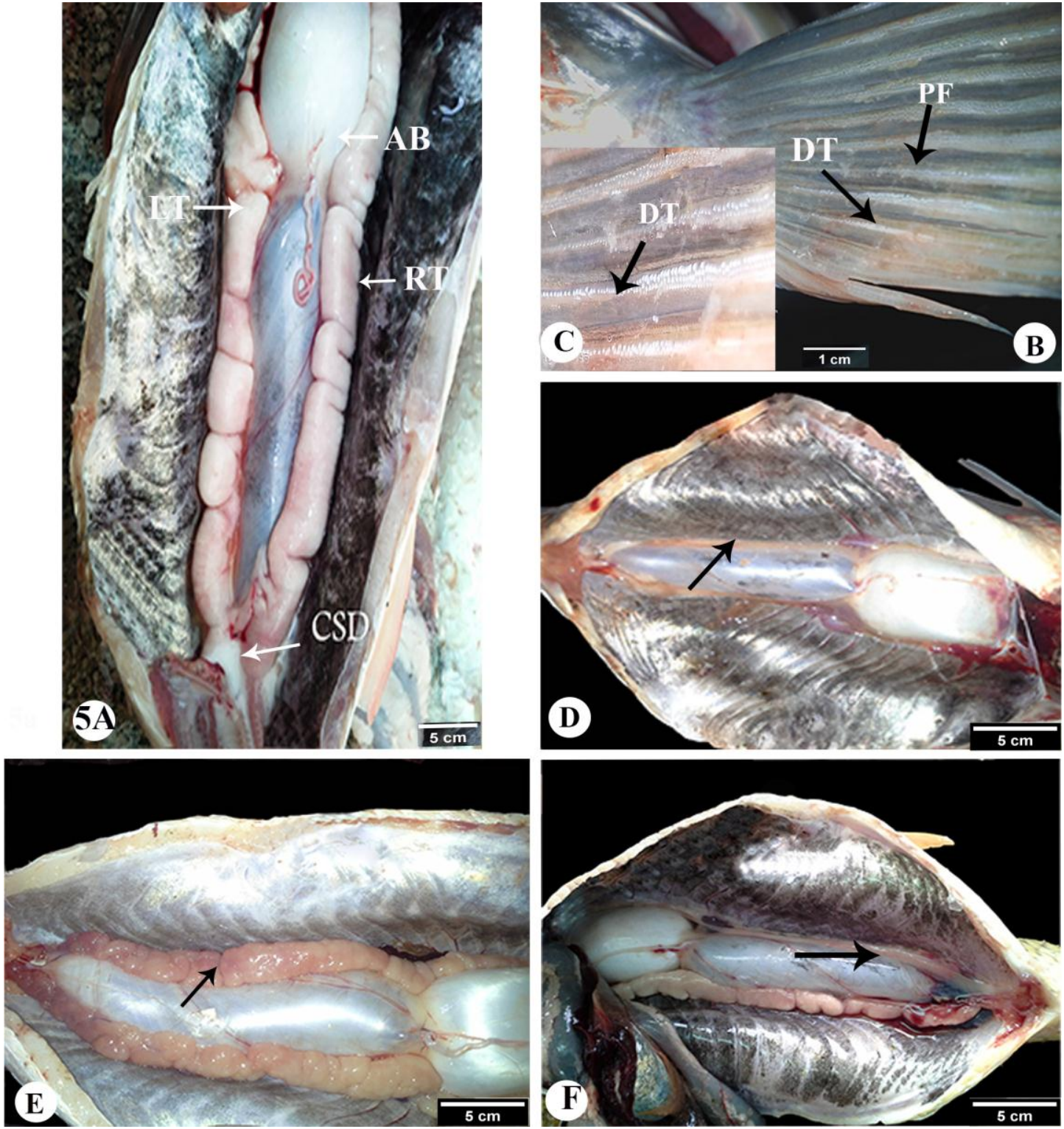

Fig. (5): Photomcrograph of the dissected testes of male grass carp. (A), Showing the ripe stage of right testes (RT), left testis (LT) and common spermatic duct (CSD) swim bladder (AB).B.. Shwing the dorsal and medial surfaces of the pectoral fins (PF) and the deciduous tubercles (DT). C. Showing magnified portion of the pectoral fins (PF) with deciduous tubercles (DT). D. Showing iImmature tests (solid arrow). E. Showing maturing tests (solid arrow). F. Showing spent stage of the testis (solid arrow). Bar $(\mathrm{A}-\mathrm{F})=5 \mathrm{~cm}$. 


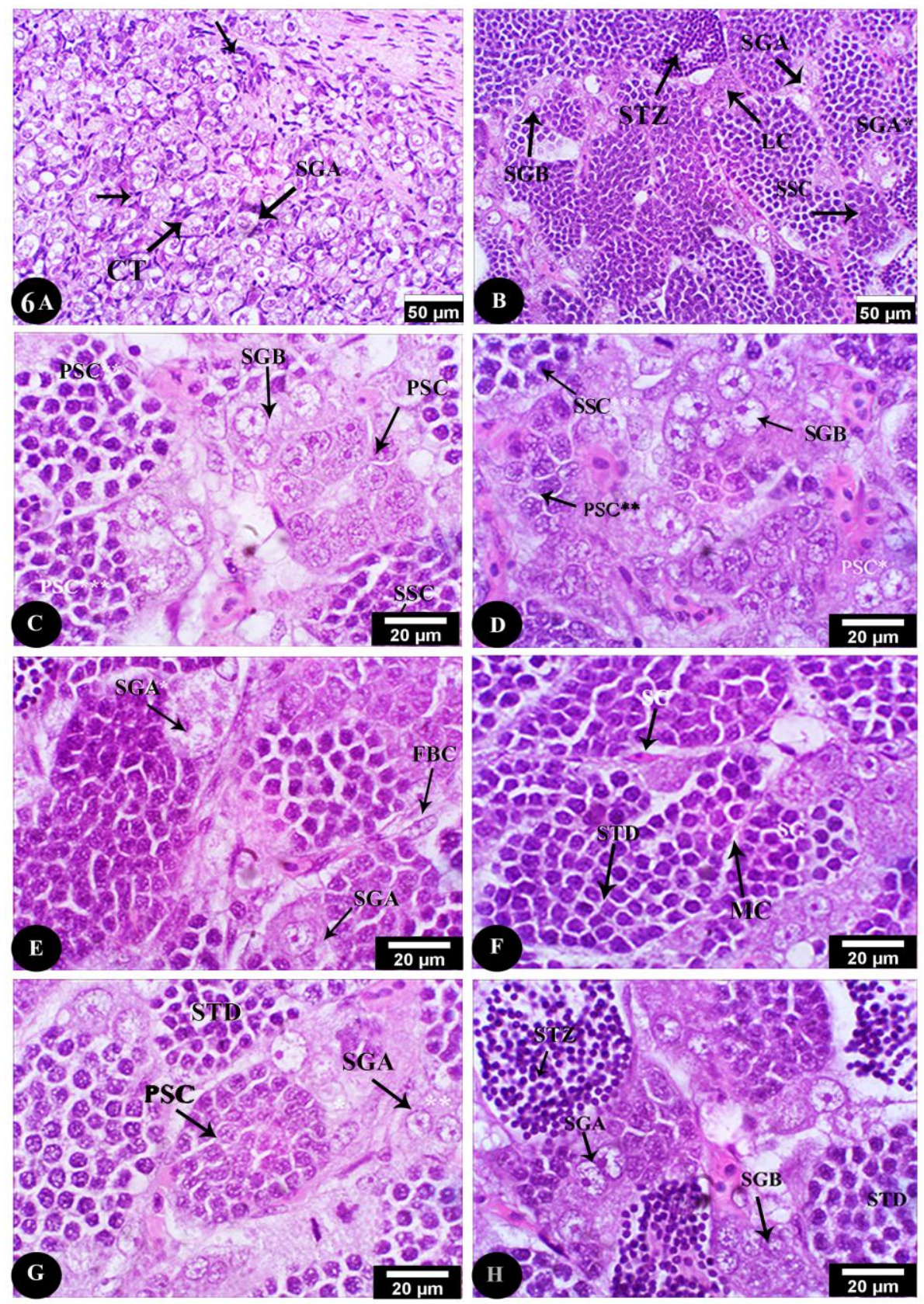

Fig. (6): (A): Photomicrograph of a cross histological section in. the testis during immature stage. Showing the testicular lobules compacted with spermatogonia A (SGA), the connective tissue (CT) (solid arrow) $\operatorname{Bar}(\mathrm{A})=50 \mu \mathrm{m},(\mathrm{B})$ : Cross section during the maturing stage. Showing spermatogonia A division (SGA*), spermatogonia B (SGB) secondary spermatocytes (SSC) and Leydig cells (LC), (C): Maturing stage, spermatogonia B (SGB) under division to give primary spermatocytes (PSC*) and secondary spermatocytes (SSC). (D,E): Maturing stage spermatogonia B (SGB) and primary spermatocyte (PSC**) and secondary spermatocytes (SSC), fibroblasts cells, (FBC), (F): Showing the spermatid (STD) cells were enclosed together in membranous cysts (MC) of sertoli cell (SC), (G): Maturing stage, Showing cytoplasm of spermatogonia A (SGA) contains two nucleoli ** and other under division**, $(\mathrm{H})$ : Magnified portion of the testis in maturing stage. $(\mathrm{H})$. Showing bucket of spermatogonia B (SGB) and spermatogonia A (SGA) and spermatid (STD) and first appearance of sperms (STZ). (H and E.). Bar $(\mathrm{A}, \mathrm{B})=50 \mu \mathrm{m}, \mathrm{Bar}(\mathrm{E}-\mathrm{H})=20 \mu \mathrm{m}$. 

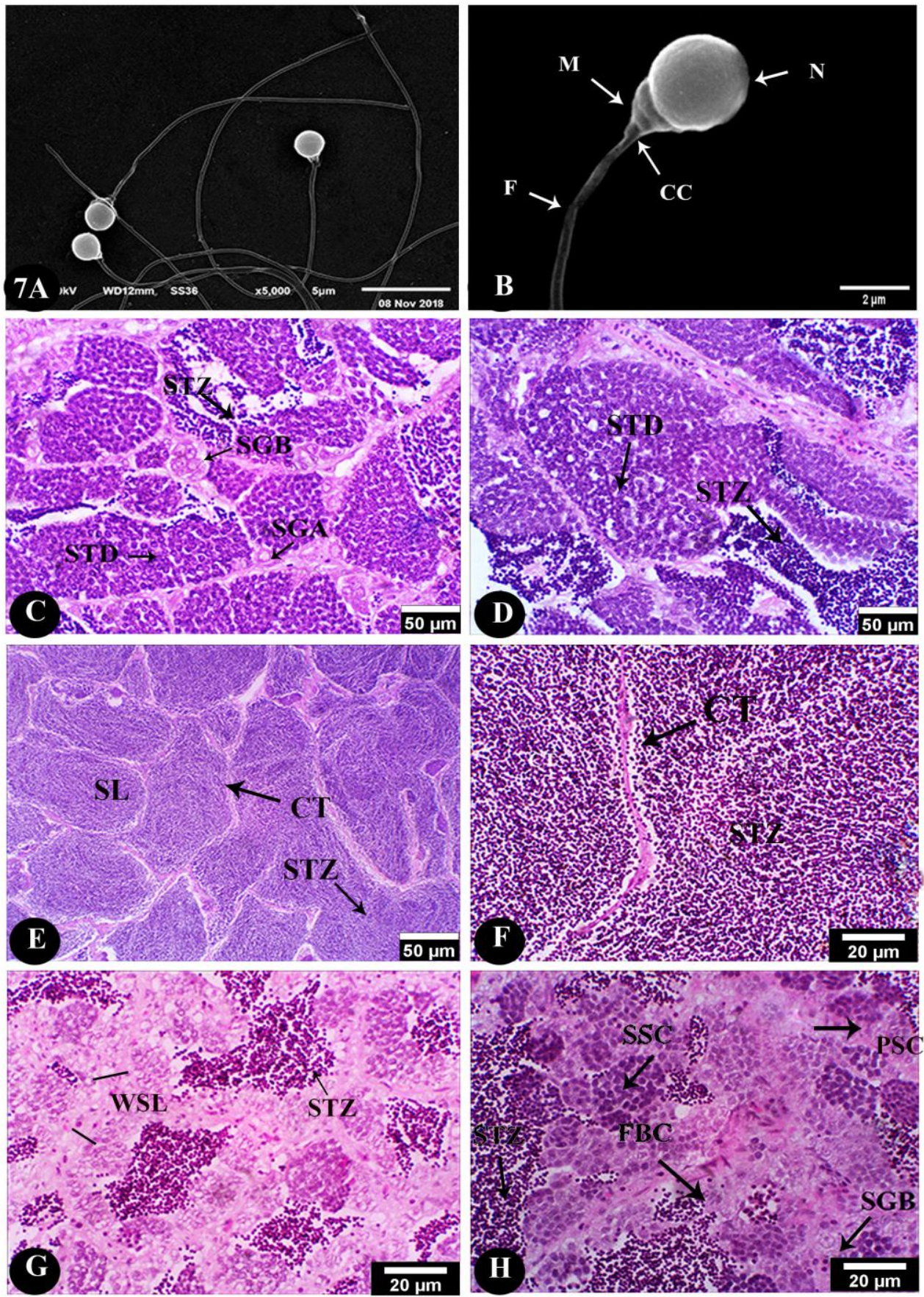

Fig. (7): A\&B.-Scanning electron micrograph of sperm cell. $\mathrm{Bar}=8 \mu \mathrm{m}$. Note nucleus $(\mathrm{N})$, mid piece $(\mathrm{M})$, flagellum $(\mathrm{F})$, and cytoplasmic channel $(\mathrm{CC})$. Bar $=2 \mu \mathrm{m}$. C. Cross histological section during maturing stage showing abundant of spermatids (STD) beside secondary spermatocytes (SSC) and some spermatogonia B (SGB). D. Showing release of sperms (STZ) to the centers of the lobules. E. Ripe stage showing the spermatozoa (STZ) accumulated inside the seminiferous lobules (SL) and the tubules separated by thin connective tissue (CT). F. Magnified portion of ripe stage. G. Spent stage showing remnant spermatozoa (STZ) thickened wall of seminiferous lobules (WSL). H. Newly sprout of spermatogenesis and presence of spermatogonia $B(S G B) . B a r(C, E)=50 \mu \mathrm{m}, B a r(F, H)=20 \mu \mathrm{m}$. 


\section{Annual variation of the GTH cells during the annual cycle:}

The gonadotropic hormone secreting cells (GTH) showed dramatically changes in size, number and the affinity to stain during the annual cycle of male grass carp. The GTH cells showed pronounced cytological changes commenced with the maturation of gonadal cycle. According to changes of testicular maturation events and the changes of GTH cell numbers, size and affinity to staining, the annual variation of GTH classified into four stages Resting stage (immature and maturing), ripe, spawning and Spent stages.

\section{1-Resting stage (immature and maturing):}

The resting stage was considered as the dominant stage along the annual cycle. During the resting period, the testes that comprise immature spermatogenic cells (Figs. 7C, D). The GTH cells were localized mainly in the PPD; and spread between

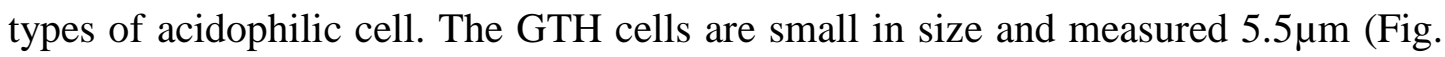
$8 \mathrm{C})$.

\section{2-Ripe stage}

From the end of March to the end of June all male reached to the ripe stage and the testis became entirely filled with spermatozoa and wait the suitable condition to fertilize the ovulated egg (Figs. 7 E, F). During ripe stage the PPD become filled with GTH cells, since the basophilic GTH increase in size (Figs. 8 D, E). The granulation of cytoplasm reached to the maximum degree and the size of GTH increased and recorded $11.2 \mu \mathrm{m}$. The GTH cell seems to be as a bag of secretory granules (Fig. 8E). The vacant areas between the GTH cells decreased and seem to be as a compacted cell mass. With acceleration testis maturation the degranulation of secretory granules of GTH cells (Figs. 8 F, G)

\section{3-Spawning stage:}

This stage was not detected during the period of spawning season.

\section{4-Spent stage:}

During the period from the middle of July to the end of September, the spent stage was dominant in the testis, since the remnant of spent testes was detected Figs.7 $(\mathrm{G}, \mathrm{H})$. The affinity of GTH cells for staining was very weak and considered as indication of the presence of few granules. Few number of GTH cells were granulated and most of the GTH cells became vacuolated measuring about $5.66 \mu \mathrm{m}$ in diameter (Fig. 8H). 

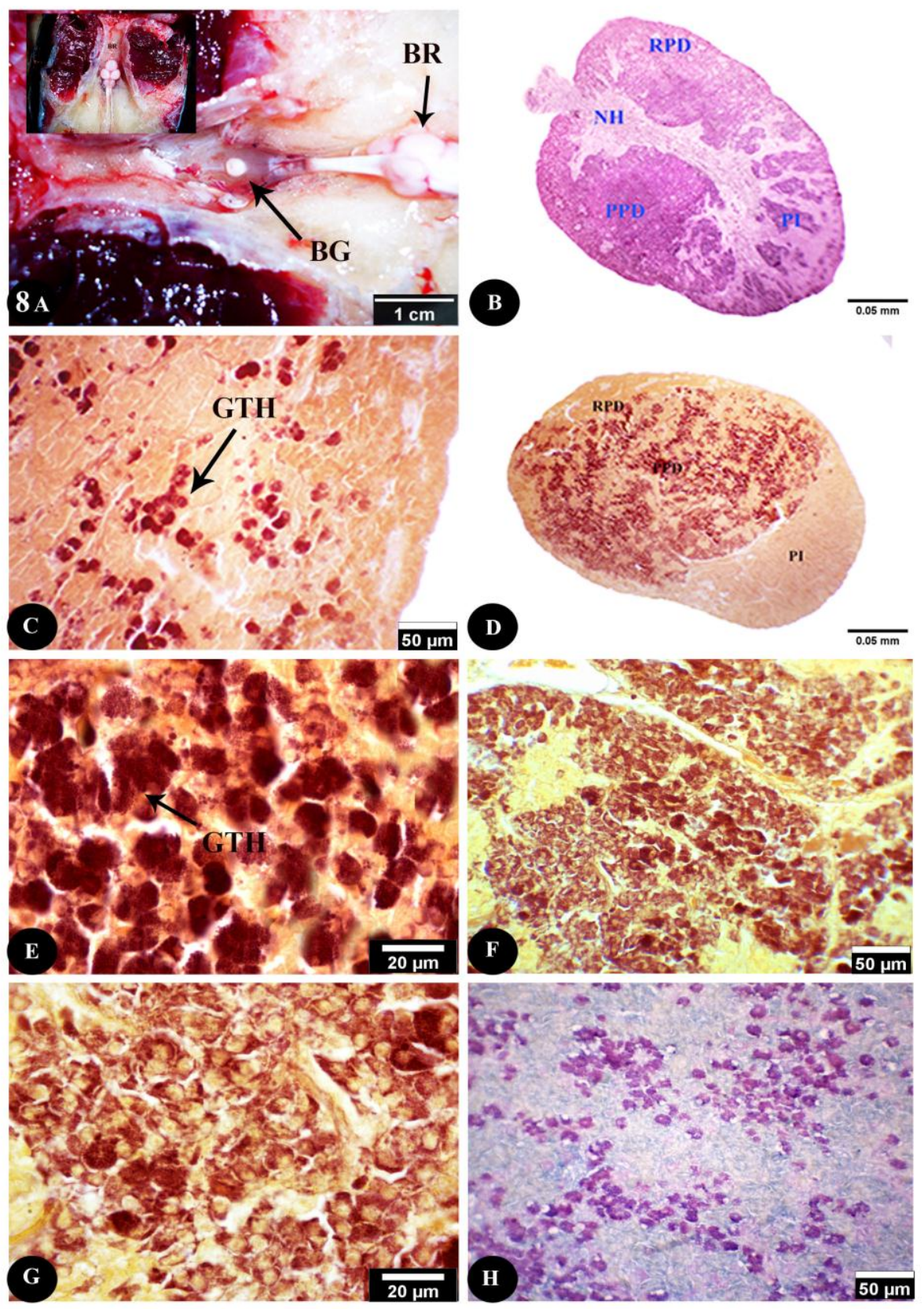

Fig. 8. A \& B: Photomacrograph of dissecting pituitary gland. Note the pituitary gland (PG) appeared oval shaped. Abbreviations; BR, pituitary. Bar $(\mathrm{A})=1 \mathrm{~cm}$. C-H. Photomicrographs of sagittal histological sections of pituitary gland. Proximal pars distalis (PPD), rostral pars distalis (RPD), and pars intermedia (PI), C. Basophilic GTH appeared as island in PPD during the period of immature stage. (PAS and Orange- G). D.GTH cells abundant in PPD during ripe stage (PAS and Orange- G). E. Higher magnification of PPD during ripe stage showing numerous GTH stained with dark magenta red color, F\&G. Spent stage showing vacuolization of basophilic GTH cells. (PAS-OG,). H. Showing small amount of basophilic GTH cells infiltrated between acidophilic cells (during the spent stage). (AB-PAS-OG,), $\operatorname{Bar}(C, F, H)=50 \mu \mathrm{m}, \operatorname{Bar}(E, G)=20 \mu \mathrm{m}, \operatorname{Bar}(B, D)=0.05 \mathrm{~mm}$. 


\section{DISCUSSION}

The present study found that the first sexual maturity of male grass carp in River Nile was predicted at $53 \mathrm{~cm}$ in length. The population of grass carp (Kapchagay), matured at length ranged from 30-60 cm SL, but the majority of fishes (50-70\%) reached maturity at the body lengths of $35-50 \mathrm{~cm}$. The presen findings agree with the studies carried out by Abou Shabana et al. (2012) who reported the maturity of male Argyrosomus regius fishes at $45 \mathrm{~cm}$.

In Uzbekistan, Kamilov and Komrakova (2003) studied the growth and maturation of the Ctenopharyngodon idella, and confirmed that male mature when they reach 50-60 $\mathrm{cm}$ at age 3 years. Also, in case Cyprinus carpio the male sizes at first maturity were $27 \mathrm{~cm}$ (Abera et al., 2015). In Indonesia, Oktaviani et al. (2018) studied biological aspects of Pentaprion longimanus, and found that the mature fish length ranged between 7.4 to $15.3 \mathrm{~cm}$. Oliveira et al. (2015) studied on Hemiramphus brasiliensis and reported that the length at the first sexual maturation of males was $20.8 \mathrm{~cm}$. . Abu El-Nasr (2016) reported in the testis maturation of Gerres filamentosus, was equal to $16.63 \mathrm{~cm}$ in length.

The difference of the length at first sexual maturity may be due to the impact of geographical variation that associated with different environmental conditions and accessibility of the food chain as stated by Krishnamurthy and Krishnamurthy (1976) and Brown-Peterson and Warren (2001). With the transition in geographical position, the first sexual maturity changed between species and also in the same species.

Also, the testes gradually increase in weight from the immature stage to the ripe stage and returned to decrease in size again during spent stage. These were observed by a variation of GSI value, since the value being the lowest in the resting stage, and then gradually increased reached the highest level during the ripe stage. These results were consistent with Rheman et al. (2002) and Chakrabarti and Bose (2014) in Liza parsia.

Furthermore, the testes weight gradually increase from the immature to the ripe stage and returned to decrease again during spent stage. These were confirmed by the variance of GSI value, where the lowest value recorded in the resting period, and then gradually increased reached the highest value during the ripe stage. These results were agree with the studies carried out by Rheman et al. (2002) and Chakrabarti and Bose, (2014) in Liza parsia.

In addition, the spermatogenesis started by the active of mitotic division of the spermatogonial cells which is the more largest one. It is the stem mother of spermatogenesis in male grass carp. Their numbers varied in testicular lobules of the immature stage and to a reduced one in the ripe and spent stage. Similar studies were illustrated by. Lo Nostro et al. (2003) in case Synbranchus marmoratus. Uribe et al. (2014) reported that the spermatogonial is the main issue of spermatogenesis.

According to the classification of Grier (1981), the grass carp testes was considered to be the unregulated type because spermatogonia was found lining the inner surface of the testicular lobules. These findings agree with Çek and Yilmaz (2007) in 
Clarias lazera. Also, the spermatogonia developed into spermatozoa within the cyst structure during the spernatogenesis of the grass carp. Van Dyk and Pieterse (2008) also recorded these findings in Clarias lazera. Also, five spermatogenic cells were identified in testes of grass carp. These were closely resemble that in Salmo trutta (Dziewulska and Domagała, 2003), Gerres oyena (Abu El-Nasr, 2016), Loricariichthy (Duarte et al., 2017) and Xenentodon cancila (Chakrabarti, and Banerjee, 2015). The frequency percentages of the different germ cells occurring in the testicular lobules were used for classification of fish testis Chakrabarti and Choudhury (2015).

Furthermore, in combination with the involvement of spermatogonia, the Sertoli cells formed a projection membrane around the primary spermatocytes. Similar observations were reported by Uribe et al. (2014) who found that the Sertoli cells are involved in the development of spermatocytes cysts. The Sertoli cells were found to play important roles in the synthesis of hormones that regulating reproduction (Mousa, 1994). Andrade et al. (2001) added that the mechanism of phagocytosis of residual spermatozoa within the lobules was the key function of Sertoli cells in fishes.

In both the primary and secondary spermatocytes, the nuclear chromatin condensation also started and become evident in the spermatid. During spermiogenesis, the sperm was characterized by three distinct regions; the ovoid head with concentrated nuclear chromatin, mid piece and single long tail (flagellum). Similar findings were reported in Tinca tinca (Psenicka et al., 2006) and Sahyadria denisonii (Sajan and Mercy, 2016). The number, shape, size, and structure of flagellum varied between teleosts and can be used in fish taxonomy (Lahnsteiner and Patzner, 1997 and Mattei and Mattei, 1974). The ripe testicular lobules were entirely filled with spermatozoa and the gonadosomatic index reached its maximum level in April. The maturation of testicles proceeded that of ovaries. This outcome was consistent with the general consideration provided by Opuszynski and Shireman (1995).

Furthermore, the pituitary gland of male grass carp lies ventral to the brain behind the optic chiasma for protection and the gland divided into neurohypophysis and adenohypophysis similar to Cyprinus carpio ( Hassanini and Shoeib, 2014) and Kharat and Nemacheilus Mooreh (Khillare ,2013). The GTH was the only cell type exhibited a degree of granulation and hypertrophy during the sexual maturation. These findings agree with the study carried out in pituitary gland of Bagrus bajad (Elgamal and El- Gresisy, 2008) and Mugil caphalus (Mousa, 1994).

The cyclic change in basophilic cell GTH accelerated testicular development during mature stage. However, the GTH were small in number, less differentiated and restricted in PPD during resting phase. During maturation of testes, the size and number of the GTH attained its maximum activity. The GTH cells become granulated and most of them exhibited vacuolated cytoplasm during the spawning and spent stage. These findings were consistent with AL-Absawy (2008) following studying pituitary of Oblada melanura. 


\section{CONCLUSION}

It can be concluded that there is a strong correlation between the testicular maturation of the grass carp and the activity of gonadotrophic cells. The length assessment that predicted the first sexual maturity of the male was $53 \mathrm{~cm}$, where $50 \%$ of the males were mature.

\section{REFERENCES}

Abera, L.; Getahun, A. and Lemma, B. (2015). Some aspects of reproductive biology of the common carp (Cyprinus carpio) in Lake Zeway, Ethiopia. Global Journal of Agricultural Research and Reviews, (3):151-157.

Abou Shabana, N. M.; Abd El Rahman, S. H.; Al Absawy, M. A. and Assem, S. (2012). Reproductive biology of Argyrosomus regius (Asso, 1801) inhabiting the south eastern Mediterranean Sea, Egypt Egyptian Journal of Aquatic Research, (38): 147-156.

Abu El-Nasr, T. (2016). Histological changes in the testis of the fish Gerres filamentosus (Cuvier, 1928) during the reproductive cycle in the Hurghada Rea Sea Egypt 5th International Conference on Agriculture, Environment and Biological Sciences (ICAEBS-16) April 28-29, 2016 Pattaya (Thailand).

Ahmet, A.; Cemil, K. and Hakanm, B. (2004). Reproductive Biology in a Native European Catfish, Silurus glanis L., 1758, Population in Menzelet Reservoir. J. Vet. Anim. Sci., (28):613-622.

Al-Absawy, M. A. (2008). Histochemical and fine structure studies of cell type identification, localization and seasonal variation in pituitary gland in relation to gonadal maturation of Oblada Melanura Egyptian Journal of aquatic research. ISSN: 1687-4285, 34(1): 209-226.

Andrade, R. F.; Bazzoli, N.; Rizzo, E. and Sato, Y. (2001). Continuous gametogenesis in the neotropical fresh water teleost, Bryconops affinis (Pisces Characidae). Tissue and Cell, (33):525-532.

Assem, S. S. (2004). Histological studies, cell types distribution and seasonal variation pituitary gland of female Dicentrarchus labrax in relation to maturation of gonadsEgyption Journal of aquatic research, 30(B):374-389. 
Brown-Peterson, N. J. and Warren, J. W. (2001). The reproductive biology of spotted sea trout, Cynoscion Nebulosus, along the Mississippi Gulf Coast. Gulf of Mexico Science, (19):61-73.

Chakrabarti, P.and Bose, S. (2014). Cyclical rhythms in the cytomorphology of testis of brackish water grey mullet Liza parsia (Hamilton, 1822) inhabiting south-eastern coast of India. International Journal of Fisheries and Aquatic Studies Studies, (2):110-118.

Chakrabarti, P. and Banerjee, A. S. (2015). Histological findings and seasonal distribution of different germ cells in the testicles of freshwater needle fish, Xenentodon cancila (Hamilton) P. International Journal of Fisheries and Aquatic Studies, 2(3):74-80.

Chakrabarti, P. and Choudhury, S. H. (2015). Morpho-Histological architecture of various cells with special emphasis on the seasonal variations of gonadotrophs in the pituitary gland of Notopterus notopterus (Pallas, 1769) in relation to testicular maturation. Journal of Entomology andZoology Studies, 3(2): 297-304.

Chilton, E. W. and Muoneke, M. I. (1992). Biology and management of grass carp (Ctenopharyngodon idella, Cyprinidae) for vegetation control: a North American perspective. Rev. Fish Bio., (2):283-320.

Duarte, S.; Araújo, F. G.; Sales, A. and Bazzoli, N. (2017). Morphology of Gonads, Maturity and Spawning Season of Loricariichthys spixii (Siluriformes, Loricariidae) in a Subtropical, Reservoir Brazilian Archives of Biology and Technology, 50 (6):1019-1032.

Dziewulska, K. and Domagała, J. (2003). Histology of salmonid testes during maturation Reproductive Biology, 3(1):47-61.

El-Gamal, A. (2001). Biological studies on the production of common carp, Cyprinus carpio. Bull. Natl. Inst. Oceanogr. Fish., A. R. E., (27):387- 403.

El-gamal, A. E, and El-greisy, Z. A. (2008). Seasonal changes of testicular maturation related to gonadotrophic cells activity of Bagus bayad (order Siluri Forms Family Bagridae) in the northern region of River Nile. Journal of Natural History, 4(I): 25-46.

El-Gharabawy, M. M.; EL-Serafy, S. S.; Assem, S. S.; Kaldus, S. K. and EL-Asawy, M. G. (2003). The reproductive biology, histology and ultrastructural characteristics of the ovary of the pelagic Carangid Trachinotus ovatus from the Egyptian Mediteranean water. Bull. Fac. Sci., Assut, Univ., 32 (1-E):25-45.

Fish Base, (2004). Entry for Ctenopharyngodon idella. Main ref.: Shireman JV, Smith CD, 1983. Synopsis of biological data on the grass carp, Ctenopharyngodon idella 
(Cuvier and Valenciennes, 1884).FAO Fish. Synop. No.135:86 pp. Online at www.fishbase.org/.

Goodchild, C. D. (1999). Non-indigenous freshwater fish utilized in the live food fish industry in Ontario: A summary of information. Ontario Ministry of Natural Resources. Ontario, Canada; p. 79

Grier, H. J. (1981). cellular organization of the testis and spermatogenesis in fishes. American Journal of Zoology, (21):345-357.

Harris, H. R. (1900). On the rapid conversion of haematoxylin into haematein in staining reactions. J. Appl. Microsc., (3): 777-780.

Hassanin, A. and Shoeib, M. (2014). Immunocytochemical and ultrastructural characterization of adrenocorticotropic cells in the pituitary gland of the carp fish (Cyprinus carpio L.) Minufiya Vet. J., 8(1):227-236.

Kamilov, B. G. and Komrakova, M. Y. (2003). Growth and maturation of the Grass Carp, Ctenopharyngodon idella, in Uzbekistan. Pakistan J. Zool,. 35(2):115-118.

Khallaf, E. A. And Authman, M. (1991). Astudy of some reproduction characters of Bagrus bayad Forskal in Bahar Shebeen Nilotica Canal.J. Egypt. Ger. Soc. Zool., (4):123-138.

Kharat, S. S. and Khillare, Y. K. (2013). Morphology and histology of pituitary gland of torrential stream fish Nemacheilus Nooreh (Sykes) Int. J. Bioassays, 02 (08):1079-1084.

Krishnamurthy, K. N. and Krishnamurthy, M. (1976). Studies on the age and growth of Indian sand whiting Sillago sihama (Forskal) from Pulicat Lake with observations on its biology and fishery. Idian J. Fish., (25):84-97.

Lahnsteiner, F. and Patzner, R. A. (1997). Fine structure of spermatozoa of four littoral teleosts Symphodus ocellatus, Corisjulis, Thalassoma pavo and Chromis chromis. J Submicr Cytol Path., (29):477-85.

Lee, D. S.; Gilbert, C. R.; Hocutt, C. H.; Jenkins, R.E.; McAllister, D. E. and Stauffer, J. R. (1980). Atlas of North American freshwater fishes. North Carolina State Museum of Natural History. Issue: 12.854 p.

Lo Nostro, F.; Grier, H. J.; Andreone, L. and Guerrero, G. A. (2003) Involvement of the gonadal germinal epithelium during sex reversal and seasonal testicular cycling in the 
protogynous swamp eel, Synbranchus marmoratus Bloch, 1795. (Teleostei, Synbranchidae). J Morphol., 258:107-126; PMID:12740902

Mattei, C. and Mattei, X. (1974). Spermiogenesis and spermatozoa of the Eiopomorpha (teleost fish). In: Afzelius BA (ed) The functional anatomy of the spermatozoon. Oxford: Pergamon Press., pp 211-21.

Mc Manus, J. F. A. (1948). Histological and histochemical uses of periodic acid stain. Technology, (23): 99-108.

Mitchell, A. J. and Kelly, A. M. (2006). The public sector role in the establishment of grass carp in the United States. Fisheries, 31(3):113-121.

Mousa, M. A. (1994). Biological studies on the reproduction of Mugil (Mugil Cephalus L.) in Egypt. PH.D Thesis Faculty of Science, Ain Shams University, Cairo, Egypt pp277.

Oktaviani, D.; Faizah, R. and Nugroho, D. (2018). Biological aspects of Longfin Mojarra (Pentaprion longimanus, Cantor 1849) in north coast of Central Java, Indonesia. Biodiversitas, (19):683-689.

Oliveira, M. R.; Silva, N. B.; Yamamoto, M. E. and Chellappa, S. B. (2015). Gonad development and reproduction of the ballyhoo half beak, Hemiramphus brasiliensis from the coastal waters of Rio Grande do Norte, Brazil J. Biol., 75(2):324-330.

Psenicka, M.; Rodina, M. and Nebesarova, J. (2006). Ultrastructure of spermatozoa of tench Tinca tinca observed by means of scanning and transmission electron microscopy. Theriogenology, (66): 1355-1363.

Rheman, S.; Islam, M. L.; Shah, M. M. R.; Mondal, S. and Alam, M. (2002). Observation on the fecundity and gonadosomatic index (GSI) of the grey mullet Liza parsia (Ham.). Journal of Biosciences, (2):690-693.

Sajan, S. and Mercy, T. V. A. (2016). Characterization of Testis and Sperm Morphology of Sahyadria denisonii (Day 1865) an Endemic and Threatened Ornamental Fish of the Western Ghats of India / Turk. J. Fish. Aquat. Sci., (16):531-538.

Sivakumaran, K. P.; Brown, P.; Stoessel, D. and Giles, A. (2003). Maturation and reproductive biology of female wild carp, Cyprinus carpio, in Victoria, Australia. Environmental Biology of Fishes, (68):321-332. 
Tan, J. D. (1985). Ahistological study of the hypophysial system during sexual maturation and spawning in milkfish, Chanos chonos (Forskal). J. Fish. Biol., (26):657668.

Tingaud-Sequeira, A.; Chauvigné, F.; Fabra, M.; Lozano, J.; Raldúa, D. and Cerdà, J. (2008). Structural and functional divergence of two fish aquaporin-1 water channels folowing teleost-specific gene duplication. BMC Evolutionary Biology, (8):259.

Uribe, M. C.; Grier, H. J. and Mejía-Roa, V. (2014). Comparative testicular structure and spermatogenesis in bony fishes, Spermatogenesis, 4:3, e983400,

Van Dyk, J. C. and Pieterse, G. M. A. (2008). Histo-morphological study of the testis of the sharp tooth catfish (Clarias gariepinus) as reference for future toxicological assessments. Journal of Applied Ichthyology (24):415-422. 